\title{
Düzeltme: Hotel Managers' Consciousness toward Competition and Its Strategies
}

\section{Eda Rukiye DÖNBAK ${ }^{1}$}

\section{Abstract}

The purpose of this study is to evaluate the competition perception of hotel managers within the framework of resource-based business capabilities. A qualitative research method that allows in-depth examination of the competition understanding of hotel managers was applied between 01.10.2019 and 24.10.2019. According to the results of the content analysis of the hotel managers' opinions about competition, the themes of "competitor's business structure and facilities", "monitoring the external environment", "industry experience of the manager", "using statistical data", "price reduction" and "service quality" were obtained. When the managers' perspectives on the relationship between distinctive abilities and competition were evaluated, it was seen that themes as "information technologies capability", "customer relationship capability", "hotel's employment policy" and "employee turnover" rate were formed. When the content analysis conducted according to the innovative product and service understanding of the managers was evaluated, the use of online channels and different service concept themes were obtained. The national and international market themes were obtained according to the managers' evaluations on differentiation strategies. Differentiation strategy for international markets and cost-oriented differentiation strategy weren't evaluated by most hotel managers. The findings from the study are expected to contribute to RBV-based competition studies for the hospitality industry.

This article is a revised version of the article referenced "Dönbak, E. R. (2020). Hotel Managers' Consciousness toward Competition and Its Strategies. Journal of Hospitality and Tourism Issues, 2(2), 143-160". https://dergipark.org.tr/tr/pub/johti/issue/58847/780548

Key Words: Resource Based View, Organizational Capabilities, Competitive Strategies

Jel Code/Kodu: M1, M10, M12, M19

\section{Otel Müdürlerinin Rekabet ve Stratejilerine Yönelik Anlayışları}

\section{Özet}

Bu çalışmanın amacı, otel yöneticilerinin sahip olduğu rekabet algısının kaynak temelli işletme yetenekleri görüşü çerçevesinde değerlendirilmesidir. Bu çalışmada otel yöneticilerinin rekabet anlayışının derinlemesine incelenmesine olanak tanıyan nitel araştırma yöntemi otel yöneticilerine 01.10.2019 ve 24.10.2019 tarihleri arasında uygulanmıştır. Otel yöneticilerinin rekabete ilişkin görüşlerinin tematik içerik analizi sonuçlarına göre, "rakibin iş yapısı ve tesis imkânları", "dış çevreyi izleme", "yöneticinin sektör deneyimi”, "istatistiksel verileri kullanma", "fiyat indirimi"," hizmet kalitesi" temaları elde edilmiştir. Yöneticilerin ayırt edici yetenekler ile rekabet arasındaki ilişkiye bakış açıları değerlendirildiğinde, "bilgi teknolojileri yeteneği", "müşteri ilişkileri yeteneği", "otelin istihdam politikası" ve "çalışan devir hızı" temalarının oluştuğu görülmüsstür. Müdürlerin yenilikçi ürün ve hizmet anlayışlarına göre yapılan içerik analizi değerlendirildiğinde ise "online kanalların kullanılması" ve "farklı hizmet konsepti" temaları elde edilmiştir. Yöneticilerin farklılaştırma stratejileri konusundaki değerlendirmelerine göre "ulusal pazar" ve "uluslararası pazar" temaları elde edilmiştir. Uluslararası pazarlara yönelik farklılaştırma ve maliyet odaklı farklılaştırma stratejileri, çoğu otel müdürü tarafından değerlendirilmemiştir. Araştırmadan elde edilen bulguların konaklama endüstrisine yönelik ve RBV temelli rekabet çalışmalarına katkıda bulunması beklenmektedir.

Anahtar Kelimeler: Kaynak Temelli Görüş, Örgütsel Yetenekler, Rekabet Stratejileri

Referans/Citation: Dönbak, E. R. (2020). Hotel Managers' Consciousness toward Competition and Its Strategies, Journal of Hospitality and Tourism Issues, Vol. 2, No.2, 143-160. 


\section{INTRODUCTION}

Organizational capabilities imply the ability to neutralize threats in the external environment of a business through the use of internal resources in the business, and as a result, the opportunity to create competitive advantage or superiority in the business (Barney \& Hesterly, 2006). Competition strategies may develop in accordance with the resources and capabilities of the business, and they are carried out by business managers based on the basic skills of the business and in accordance with the competition balance in the sector.

The main question of this study is how much attention is paid by hotel managers to the effects of tangible and intangible business resources on the competition strategies defined by the resource-based view. The competition perceptions of human resources, including managers at hotels, will be implemented in practice with the decision of managers, in line with the capabilities of the human resources. From this point of view, this study was carried out to evaluate the scope of the competition perceptions of hotel managers from Adiyaman, and determine how important hotel employees' abilities for managers are and how they are taken into account while determining the competitive strategies they will implement.

\section{CONCEPTUAL FRAMEWORK}

The Resource Based Business Capabilities Theory basically expresses the total of a firm's capabilities and resources (Wernerfelt, 1984), while according to Amit and Schoemaker (1993), it expresses the sum of all factors that can be controlled by the firm and that it can be used efficiently in "desired scales". Snow and Hrebiniak (1980) concluded that companies with distinctive abilities have a more sustainable competitive advantage than others, provided that they examined a heterogeneous firm's abilities in terms of defensive, collaborative, aggressive and reactive competitive behavior. In their study, Barney (1991) discussed the main differences between environmental models and the resource-based view (RBV) vision to gain competitive advantage, and they concluded that obtaining sustainable competitive advantage is possible when the business can turn any resource it has into a separate capability. Sweeney et al. (2011) stated that the potential benefits that can be obtained from internal organization resources may be transformed into firm skills such as information or innovation to provide the company with a competitive advantage. Prithwiraj et al. (2010), in their research where they investigated how a firm's marketing and operational capabilities come together with the differentiation strategy in a resourcebased perspective, determined that the firm's marketing communication, customer relationship management ability increased the company performance by creating a differentiation strategy. According to RBV, all of the firm's tangible and intangible resources will be decisive for the firm's competitive strategy (González-Rodríguez et al., 2018).

Similar studies on how an organization's capabilities, which have been evaluated within the RBV framework, have affected their competitive strategies and firm performance, have also been conducted within the hospitality industry. In Ruzic's (2015) study, they observed that human resource management activities at hotels contribute to the hotel's human resources both individually and organizationally, and this effect also increases the financial performance and competitive strategies of the hotel. Ruzic (2015) stated in their study that the individual abilities of employees express their competence at work, but without HRM activities, these are insufficient for the organizational performance and competitive strategies of the hotel. In their work, Bazic and Cvelber (2016) aimed to define the sustainable competitive advantage created by business resources and abilities in the hotel industry and develop an overview of this issue. They examined the 40 most cited studies between 1996 and 2015 and reported that most of them were conducted to examine the impact of a company's intangible resources and abilities 
on the performance of hotels, and tangible business resources were little taken into account. However, in most of the studies they examined, knowledge was accepted as the main variable affecting hotels' performance. According to Ivanova and Ivanov (2016), the resource-based view presents a model for creating and maintaining a competitive advantage in the hotel industry, and it also provides a basis for sharing and managing organizational capabilities such as hotels' learning and knowledge management. González-Rodríguez et al. (2018) accepted the organizational structure and culture of a hotel, management style, staff training, the brand and brand image which is the intangible resources of a hotel that the hotel has have an indirect effect on the innovative differentiation strategy of the hotel and increase the hotel's market performance. Köseoğlu et al. (2019) investigated how hotel managers from middle and high level and various departments reflected their competitive intelligence on their organizational, operational and strategic levels. The main findings of their work were that daily operations are used for organizational-level strategies, middle and lower-level departmental managers collect data formally and informally about competition intelligence during daily operations and are used to implement competitive strategies determined by hotel managers. Based on these examples in the literature, one may state that the competition strategies applied in the hotel sector are based on the view of competition based on resources. However, it is seen that competitive strategies are formed by monitoring the environment in the hotel sector. For instance, Köseoğlu et al. (2016) explained that they investigated competition intelligence in the hotel industry, and related studies, which had both conceptual and experimental methods, established a direct relationship between environmental scanning (ES) especially for the food and accommodation units of hotels and hotel performance and competition strategy. In their other findings regarding inclusion of competitive intelligence in the process, it was stated that the managers of hotels in competition have information about each other via the internet (social media, Expedia etc.) and from reporting sites such as Star Reports and Hotelligence, while the same managers' way to obtain another information is to travel around by car in order to obtain information about the occupancy rate of their competitors, call by phone to other hotels like a mystery customer and receive information, some of them tried to make decisions on operational matters such as extending the stay of customers by negotiating with the oil companies in the region.

\section{METHOD}

In this study, a qualitative research method that allows in-depth examination of the competition understanding of the managers of hotels established in Adiyaman was applied. Qualitative research is a type of approach to investigate and understand the meaning that individuals or groups attribute to social issues (Creswell, 2014). Since the perceptions of hotel managers about the concept of competition are suitable for in-depth and thematic evaluation, the phenomenology pattern was used. While descriptive phenomenology describes people's perceptions and experiences, interpretive phenomenology focuses on the meanings embedded within the life experiences of individuals (Akyol et. al., 2020). Descriptive phenomenology was used in this study because it was aimed to examine how hotel managers understand and experience the concept of competition.

\subsection{Sample}

In this study, hotels in the central district of Adiyaman were evaluated. The province of Adiyaman is located within the specific zone that is given priority for development in Turkey. Turkey is divided into 26 regions with a lower level of statistical classification, and Adiyaman is in the TRC1 Region. Economic analysis for these regions, and accordingly policy, are important. The TRC1 Region, in both 
social and economic sense, has serious development differences within. In this respect, Adiyaman has lagged behind other cities in the region in tourism, health and agriculture.

According to the data of the Provincial Directorate of Culture and Tourism, there are five four-star hotels and five three-star hotels with a Business Certificate from the Ministry of Culture and Tourism in the central district of Adiyaman. There are six two-star hotels with a municipal certificate. Apart from these, the training hotel, which was established on a university campus and has a business certificate of the Ministry of Culture and Tourism, was selected to represent the public guesthouses in the city. Two 3star hotels and two 4-star hotels, whose address and contact details were declared on the site of the Tourism and Provincial Culture Directorate, were not included in the study because they did not operate during the study period. Considering the official data of the hotel classes in the city and when we evaluated the data we obtained from the first four interviews, we decided not to expand the sample because the coding results were very close to each other. Five hotels that were considered to represent each class were identified. Semi-structured meetings were held with these five hotels' managers between the dates of 01.10 and 24.10.2019. By making an appointment with each of the hotel managers, a visit was made to their offices, they were interviewed at their most convenient time, and the interviews were recorded by taking their permission.

Table 1. Information about participants

\begin{tabular}{|c|c|c|c|c|c|c|c|c|}
\hline Managers & Age & Sex & $\begin{array}{c}\text { Educational } \\
\text { Level }\end{array}$ & $\begin{array}{c}\text { Educational } \\
\text { Area }\end{array}$ & $\begin{array}{c}\text { Sectoral } \\
\text { Experience }\end{array}$ & $\begin{array}{l}\text { Managerial } \\
\text { Experience }\end{array}$ & Position & $\begin{array}{l}\text { Scale of } \\
\text { Hotels }\end{array}$ \\
\hline M1 & 32 & Male & $\begin{array}{l}\text { Bachelor's } \\
\text { Degree }\end{array}$ & $\begin{array}{c}\text { Tourism and } \\
\text { Hotel } \\
\text { Management }\end{array}$ & 17 years & 6 years & $\begin{array}{l}\text { General } \\
\text { Manager }\end{array}$ & 4 Stars \\
\hline M2 & 39 & Male & $\begin{array}{l}\text { Bachelor's } \\
\text { Degree }\end{array}$ & $\begin{array}{c}\text { English } \\
\text { Language } \\
\text { and Literate }\end{array}$ & 24 years & 8 years & $\begin{array}{l}\text { General } \\
\text { Manager }\end{array}$ & 2 Stars \\
\hline M3 & 44 & Male & $\begin{array}{l}\text { Primary } \\
\text { School }\end{array}$ & - & 28 years & 9 years & $\begin{array}{c}\text { F\&B } \\
\text { Manager }\end{array}$ & 4 Stars \\
\hline M4 & 40 & Male & $\begin{array}{l}\text { Bachelor's } \\
\text { Degree }\end{array}$ & $\begin{array}{c}\text { Food } \\
\text { Engineering }\end{array}$ & 1 year & 1 year & $\begin{array}{l}\text { General } \\
\text { Manager }\end{array}$ & $\begin{array}{l}\text { Training } \\
\text { Hotel }\end{array}$ \\
\hline M5 & 46 & Male & $\begin{array}{l}\text { Primary } \\
\text { School }\end{array}$ & - & 25 years & 6 years & $\begin{array}{l}\text { General } \\
\text { Manager }\end{array}$ & Stars \\
\hline
\end{tabular}

\subsection{Data analysis}

The data were analyzed with the content analysis method. While the interviews were recorded by an audio recorder, the points deemed necessary were noted. After the sound recordings were transcribed on the computer, the first step in induction-type content analysis was made, and the process of creating themes started. For the purpose of comparing, describing and defining different data (Creswell, 2013; Flick, 2013), the hotel managers' evaluations regarding the questions were combined and evaluated under sub-themes. The qualitative data were considered to be intense (Patton, 2014), the essence of the data was taken, the logical evidence framework for the investigated cases was drawn, and merging was achieved under the main themes. The data were arranged on the basis of questions, and the coding of the answers given by the participants to each question was performed manually with the notes on the edges of the papers. Codes were created by repeating and interpreting the responses repeatedly at certain intervals instead of a pre-generated code list and concepts. In order to form a meaningful whole with the resulting themes and the data under them and to control the themes' ability to explain the data obtained from the study in a meaningful way, a comparison of the code and themes was made with an expert, and a $80 \%$ consensus was obtained. The findings part of the study is arranged in tables to correspond to the 
codes and themes by using tags such as M1, M2, for each manager, and their expressions are quoted under the tables.

\section{FINDINGS}

In this section, the findings that emerged as a result of the content analysis of the opinions of the managers at the hotels where the research was carried out regarding competition and organizational skills are presented. The findings obtained from this study consisted of the main themes of "Competitive Insights of Managers", "Distinctive Skills and Competition", "Innovative Product and Service Understanding of Managers", "Differentiation Strategies of Managers", "Cost Sensitivity" and "Understanding of Price and Cost Balance in Managers".

Table 2. Consciousness of managers about competition

\begin{tabular}{|c|c|c|c|c|}
\hline \multirow{2}{*}{$\begin{array}{c}\text { Question } \\
1 \\
\text { Managers }\end{array}$} & \multicolumn{4}{|c|}{ What do you understand from competitive awareness in this sector? } \\
\hline & & SUB-THEMI & & \\
\hline \multirow{3}{*}{ M1 } & $\begin{array}{l}\text { Economic and } \\
\text { political } \\
\text { situation }\end{array}$ & Industry experience & $\begin{array}{l}\text { Pre-opening and } \\
\text { opening stages }\end{array}$ & \\
\hline & $\begin{array}{l}\text { Tourism } \\
\text { infrastructure of } \\
\text { the city }\end{array}$ & $\begin{array}{l}\text { National/international } \\
\text { Brand experience }\end{array}$ & $\begin{array}{l}\text { Accommodation } \\
\text { data of the city }\end{array}$ & \\
\hline & & $\begin{array}{l}\text { Competition } \\
\text { environment } \\
\text { experience }\end{array}$ & & \\
\hline \multirow[b]{2}{*}{ M2 } & $\begin{array}{c}\text { Socio-economic } \\
\text { situation }\end{array}$ & & $\begin{array}{l}\text { Flexing } \\
\text { in prices }\end{array}$ & $\begin{array}{l}\text { Equivalent } \\
\text { service }\end{array}$ \\
\hline & & & $\begin{array}{l}\text { Price } \\
\text { doesn't } \\
\text { matter }\end{array}$ & \\
\hline \multirow[t]{3}{*}{ M3 } & & & & $\begin{array}{c}\text { Affecting } \\
\text { and } \\
\text { developing } \\
\text { services }\end{array}$ \\
\hline & Tourist types & & Discount & \\
\hline & $\begin{array}{l}\text { Consumer } \\
\text { preferences }\end{array}$ & & & \\
\hline
\end{tabular}

Public sector

M4

Limited service

Table 2 continued concept

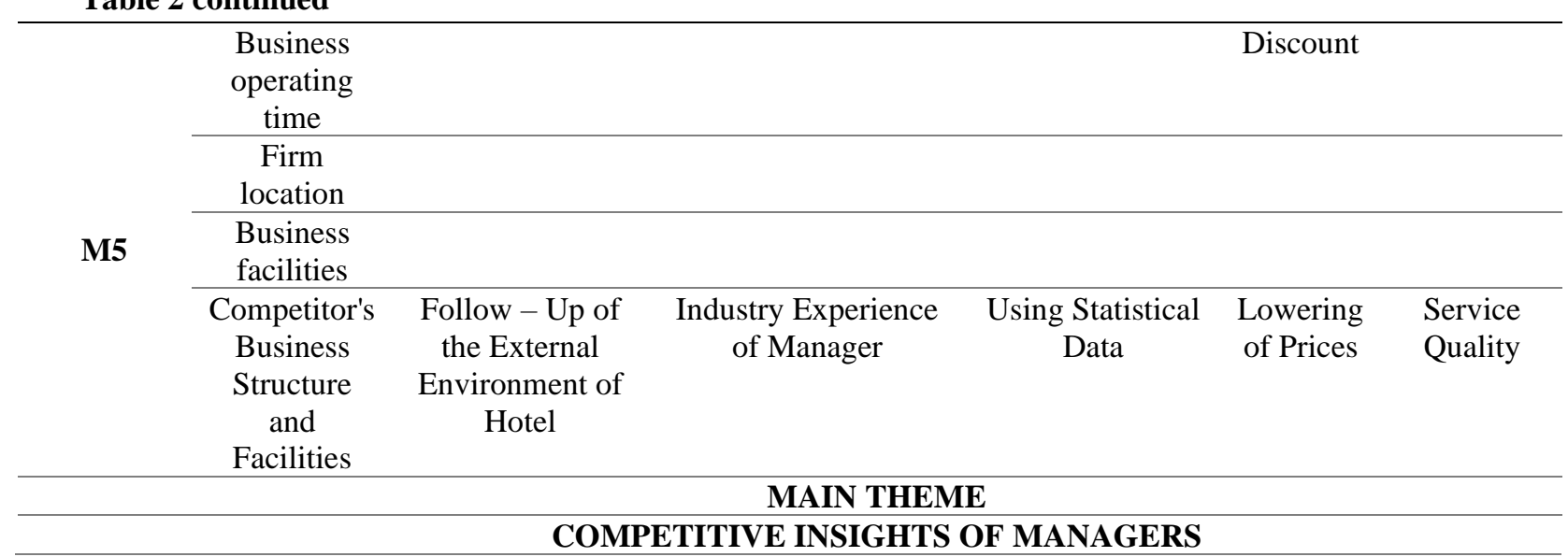


The themes that formed the insight of the managers towards competition were as "competitor's business structure and facilities", "monitoring the external environment", "industry experience of the manager", "using statistical data", "price reductions" and "service quality". The sub-themes, themes and main themes shown in Table 2 were formed based on the answers given by the managers to the first question, "What do you understand from the competition awareness in this sector," and these statements are presented in Table 2.

\subsection{Competitor's business structure and facilities}

M1;" Since the hotels I work with are national and international brands, they are corporate hotels that are always in competition. Regions were also generally competitive regions. The hotels I work with were starred with techniques based on the same national and international criteria."

M5; "Of course, I am following, of course, how other hotels are gaining customers by providing better service or by getting a price discount. According to these, I try to implement strategies. ... and I say that, if I do the following, I will gain customers as follows. Additionally, since the location of each hotel is different in this city, they all have a different market. Their possibilities are also different. For example, it has a sauna, a spa, and I think it doesn't need to go out and search for customers. Now, there are newly opened hotels, 5, 6 years after us, a hotel is more valuable than ever since everything will be new. It uses an advantage of innovation."

\subsection{External environment}

M1; "What is the economic, political, especially demographic structure of the city suitable for, how suitable is the infrastructure of the city for tourism? You have to do all this work naturally due to some situations that require being an international brand. Of course, it works incredibly well for us as managers. How will accelerations continue, up or down, and how will the situation in the country be reflected in the region? We did all this while we were in the construction phase. As a result, we have not experienced a negative situation other than the economic crisis and the rise of the dollar. In other words, we did not experience a negative situation in the region, especially cultural tours, I can say that there is no change in any negative direction."

M3; "I started to work in the 90s, and those years were more colorful. Our international tourists were in higher numbers. People living here were more social. For example, the food culture and drink culture of international tourists were different. Now, every day, we are getting worse in terms of the tourist profile. When you look at tourism in the world, we see the tourism sector that renews, grows, develops and brands. Unfortunately, this is not possible in our region and city. A Nemrut Festival was held in our city, ministers and 
politicians would definitely come. It would continue for one month, but these have somehow ended now not practiced."

M2; "Now, first of all, determining the concept in my understanding of management is very important to me. Two important things for us are to carry a mission before the competition, to create a concept, and the second is to follow socio-economic factors and then to compete."

\subsection{Industry experience}

M1; “The companies I have been working with since 2003 are national and international brands, and they are always in competition. This is why I think the corporate companies we work with give us this awareness enough."

\subsection{Using statistical data}

M1; "According to data announced by the provincial culture and the provincial tourism directorate, regarding the date our hotel was opened in 2018, there was a $100 \%$ increase in the number of tourists staying in our region and 50\% in 2019 in comparison to 2017. This was above our expectations. According to our study, this momentum will continue to rise for at least two years. We expect the competition to increase in the following process. Of course, this will also indicate that a competitive environment has started with the opening of national or international chain hotels in our region. We have completed the pre-opening and opening stages of our hotel. We have already started this work with feasibility studies. We have already done timely studies on the future of the sector in this region, the competitive situation with other hotels, that is, which brands other than us can be opened to this region."

\subsection{Lowering of prices}

M2; "Currently, the situation in Turkey is critical. In order for our work to return at a minimum, we have to stretch for the price."

M3; “...competition may create positive things. The negative side comes when prices are pulled down."

M5; "What my friends do, how they gain customers, but as far as I observe in the decisive competition, we are experiencing a price-based competition. Now, if I have three stars, I think I lost the competition when 4 stars sold rooms for a much lower price than me. There is this kind of competition mainly."

\subsection{Service quality}

M3; "Now competition is our main requirement. Competition always brings success. It also applies to hotels, so, competition may create positive things". When he evaluates his competitors, we can see the positive side of the competition when the other side is able to act and arrange him or even change his master chef."

M4; "I admit that we are in competition even if we are a public institution. We have certain limits such as the room structure of public hotels, number of rooms, limited activity areas... In order to broaden the boundaries of these areas, new activities need to create new arguments." 
Table 3. Distinctive abilities of hotel employees and competitive advantages

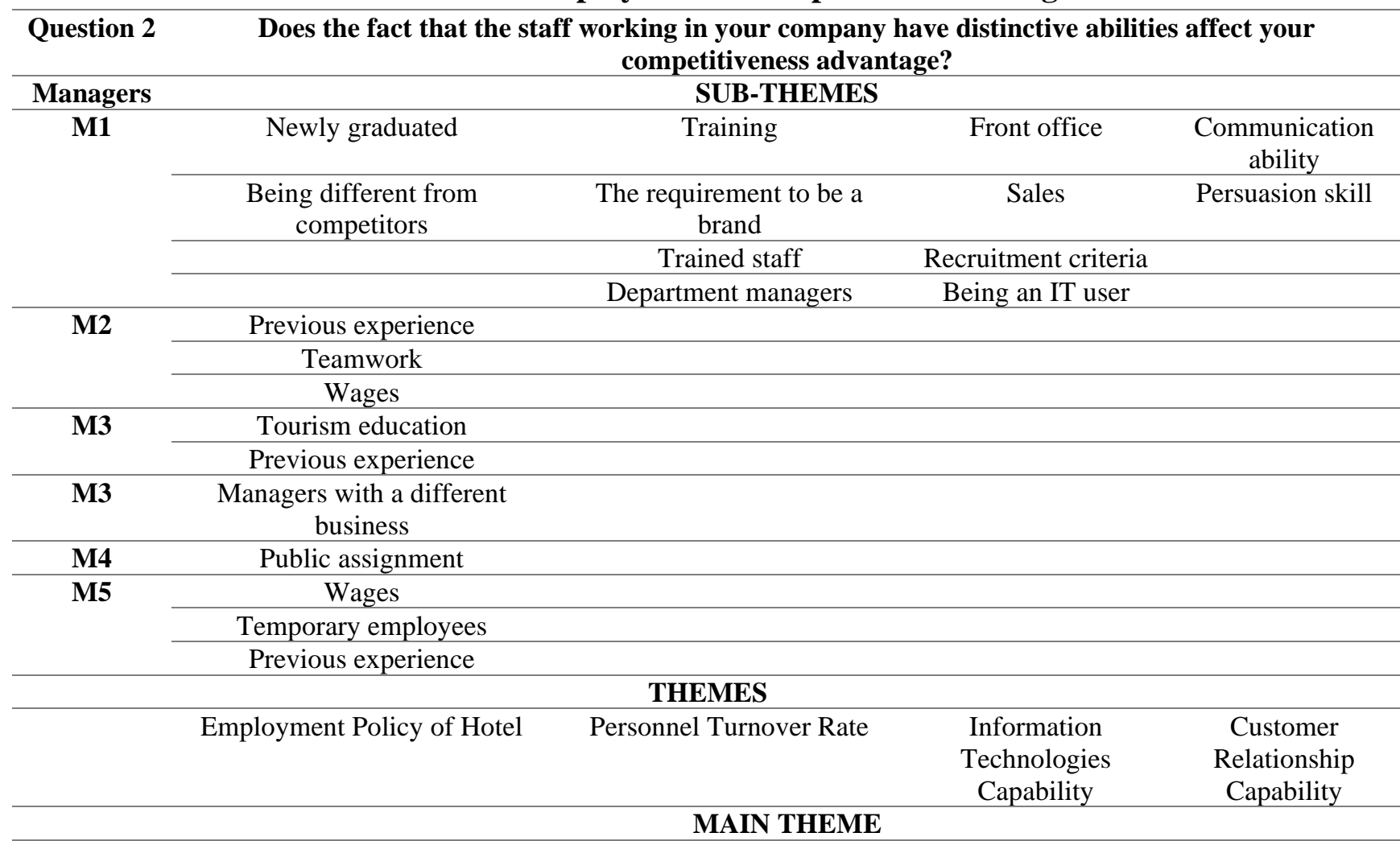

\section{DISTINCTIVE SKILLS AND COMPETITION}

The themes that formed the insight of the managers towards the relationship between competition and the distinctive skills of employees were as "employment policy of hotel", "personnel turnover rate", "information technologies capability" and "customer relationship". The sub-themes, themes and main themes shown in Table 3 were formed based on the answers given by the managers to the second question, "Does the fact that the staff working at your company have distinctive abilities affect your competitiveness advantage," and these statements are presented in Table 3.

\subsection{Employment policy of hotel}

M1; "In particular, we brought new graduates to the company and benefited from them, which made us different to other hotels here."

M2; "I absolutely care about it, staff structure is very important for us to exist in the service sector. In other words, if your staff is selfless and able to understand you, if you can work in harmony, this means that you have accomplished most of your work. Of course, this requires you to feed your staff financially, which is a bit difficult under Adiyaman conditions."

M3; "Of course, I would like to say that we actually want to work with people who have received the education of this business in essence and who carry tourism in the spirit. ...but these two do not come together. What we usually care about in job applications is which hotels they previously worked at, what their level of education is. We care about these. When operators are not very professional, there is a hitch there. So, actually, when I say that this is not my job, the man is constantly going towards a blunt." M4; "The status of the staff to be recruited is determined by public appointments."

M5; "So, of course, it is very important for them to be experienced, but they work for a short term. They look at this job as a temporary one. We cannot pay too much. A university 
graduate teenager does not settle for low wages. In other departments, we look at the experience and the hotels that they worked at before."

\subsection{Personnel turnover rate}

M1; "All of our department manager friends came from other places. Because we couldn't find local people working in this capacity and put them into work. We started with them, and we tried to gain distinguishing skills. We already provide the trainings required by our brand to them. These trainings are very important for both mental and sectoral development. We are still experiencing a shortage of qualified staff. Someone who has not received any training from scratch makes a serious effort to us, and then, because he is not aware of the sector, he can show a behavior of leaving work."

\subsection{Information technologies capability}

M1; "We are not expecting this condition to be fulfilled as we will provide certain trainings to the staff that we will start on the lowest level in the housekeeping department. However, personnel with a lack of training in departments such as the front desk and sales may be a serious source of inefficiency for us. The ability to use information technologies is important to us. ... because we have used the latest technologies as a newly built hotel, we have used advanced technology in both rooms and other units, and so, they must have knowledge and experience. Of course, we also have an IT department, but especially the front office staff should use information technologies very well, and this is reflected in the job interviews."

\subsection{Customer relationship}

M1; "Basically, the ability to communicate and persuade is very important to us. In other words, until the behaviors of the staff, from the behavior of the staff to each other, to the behaviors towards the guests, and even to the way of using materials, friends give each other their training. Our friends who have learned the simplest correct sales techniques support the reduction of our costs."

Table 4. Consciousness of managers innovative product or services

\begin{tabular}{|c|c|}
\hline Question 3 & Could you say you have innovative products or services? \\
\hline Managers & SUB - THEMES \\
\hline \multirow[t]{7}{*}{ M1 } & Service marketing \\
\hline & Corporate planning \\
\hline & Different services \\
\hline & A la Carte Restaurant Service \\
\hline & Local foods \\
\hline & Breakfasts \\
\hline & Local entertainments \\
\hline \multicolumn{2}{|r|}{ 20 } \\
\hline M3 & Hygienic dishes \\
\hline \multicolumn{2}{|l|}{ M4 } \\
\hline M5 & Close guest relationship \\
\hline \multicolumn{2}{|r|}{ THEMES } \\
\hline & Different service concept \\
\hline \multicolumn{2}{|r|}{ MAIN THEME } \\
\hline & INNOVATIVE PRODUCT and SERVICES \\
\hline
\end{tabular}

The themes that formed the consciousness of the managers towards innovative product or services were as "different service concept" and "using online channels". The sub-themes, themes and main themes 
shown in Table 4 were formed based on the answers given by the managers to the third question "Could you say you have innovative products or services," and these statements are presented in Table 4.

\subsection{Different service concept}

M1; "We definitely created this awareness even in people here. We work as a fully corporate brand, after the trainings we give to our staff and its reflection to the guests, other hotels in the city have also accepted that the services we use here and the way we market these services are different. They absolutely didn't know that before. ... because the employees of these hotels only worked in Adiyaman and learned the sector here. ...but the managers of our seven different departments all came here, gaining experience from different cities."

M3; "Yes, we did this especially in the restaurant section. Here, we try to pay more attention to preparation of food ingredients and add something every day. We are different in cleaning and hygiene."

M5; "In other words, it may be the interest that we do and offer closely, which our competitors cannot. Because we definitely remember their special days and make our gestures to them. I think we are different to our competitors in this matter."

\subsection{Using online channels}

M1; "The services we use here and the way we market these services, especially on line channels, are active as much as we can in every area, as I have already said, other hotels in the city have also accepted this situation. Not only that, this situation gives us different values due to its different mindset and perceptions. I can say that I was able to realize my different corporate plans this way."

Table 5. Differentiation strategies of managers

\begin{tabular}{|c|c|}
\hline $\begin{array}{l}\text { Question } \\
\quad 4\end{array}$ & $\begin{array}{c}\text { Do you have a plan or activity to enter different markets where your competitors are not } \\
\text { involved? }\end{array}$ \\
\hline Managers & SUB-THEMES \\
\hline \multirow[t]{4}{*}{ M1 } & Congress, fair \\
\hline & South Korea, Russia, Serbia, Ukraine, Malaysia \\
\hline & Regional promotional tours \\
\hline & Promotion budget \\
\hline \multirow[t]{2}{*}{ M2 } & University \\
\hline & Place \\
\hline \multicolumn{2}{|l|}{ M3 } \\
\hline \multicolumn{2}{|l|}{ M4 } \\
\hline \multicolumn{2}{|l|}{ M5 } \\
\hline \multicolumn{2}{|r|}{ THEMES } \\
\hline & National Local Market \\
\hline & MAIN THEME \\
\hline & DIFFERENTIATION STRATEGIES \\
\hline
\end{tabular}

The themes that formed the consciousness of the managers towards differentiation strategy were as "international market" and "national local market". The sub-themes, themes and main themes shown in Table 5 were formed based on the answers given by the managers to the fourth question "do you have a plan or activity to enter different markets where your competitors are not involved," and these statements are presented in Table 5. 


\subsection{International markets}

M1; "Let me say that we are already the hotel that participates in congresses and fairs more than other hotels in the city. We are working on this in every fair. We try to enter the markets there, especially by participating in fairs focusing on cultural tourism tours such as the Izmir fair, which we have entered as a result. Last year, we brought agents from many different countries here. We hosted most of them at our hotel for free and supported the information tours. We have agencies from S. Korea, Serbia, Russia and Ukraine. Thanks to this support, we even received a certificate of acknowledgement from TUROB (Turkey Hoteliers Association). After that, the tours started to come, and we offer hospitality services to these incoming tours here as Hilton. We used many different channels to realize our plan to acquire these new markets. We started to bring tours here, sometimes with our own resources, using private and public channels, both on a city and country scale. Now, we are waiting for tours from Serbia, Malaysia and Ukraine. ...because we especially made information tours for them, and there were not any hotels in the city that could enter these markets outside of us. While doing these, we are actually trying to contribute to the tourism of the region by allocating a budget to them as a social responsibility, which is not directly and only profitable."

\subsection{National local market}

M2; “'Where should I start?' was the first question I asked myself when I started managing this hotel. I answered as that this hotel is very close to both the university and the industry. I did a lot of market research on these two. We managed to attract this segment to ourselves because of our close location."

Table 6. Cost sensitivity of managers

\begin{tabular}{|c|c|c|}
\hline Question 5 & \multicolumn{2}{|c|}{ Do you have cost-cutting systems or practices? } \\
\hline Managers & \multicolumn{2}{|c|}{ SUB-THEMES } \\
\hline \multirow[t]{5}{*}{ M1 } & Saving measures & \\
\hline & Standard product cost & \\
\hline & Variable product cost & \\
\hline & Material use studies & \\
\hline & Motion studies & \\
\hline \multicolumn{3}{|l|}{ M2 } \\
\hline \multirow[t]{3}{*}{ M3 } & \multicolumn{2}{|l|}{ Stock system } \\
\hline & \multicolumn{2}{|l|}{ Cost, average cost } \\
\hline & \multicolumn{2}{|l|}{ Computer program } \\
\hline \multicolumn{3}{|c|}{ 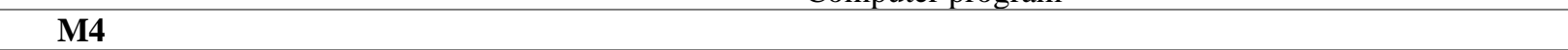 } \\
\hline \multirow[t]{2}{*}{ M5 } & & Income and expense comparison \\
\hline & & Controlling daily sales \\
\hline \multicolumn{3}{|c|}{ THEMES } \\
\hline \multicolumn{3}{|r|}{$\begin{array}{l}\text { Simple accounting } \\
\text { applications }\end{array}$} \\
\hline \multicolumn{3}{|c|}{ MAIN THEME } \\
\hline & COST SENSITIVITY & \\
\hline
\end{tabular}

The themes that formed the consciousness of the managers towards cost sensitivity were as "tight financial measures", "cost-based sales prices" and "simple accounting applications". The sub-themes, themes and main themes shown in Table 6 were formed based on the answers given by the managers to the fifth question "Do you have cost-cutting systems or practices," and these statements are presented in Table 6. 


\subsection{Tight financial measures}

M1; "Of course, as I said before, one of our brand education issues is savings points. Since these are costs for us, from the lights to the materials used by the staff for cleaning, and even to the staff's own uniforms, we also train them on their use. These are all referred to as our savings measures. Therefore, our relevant department supervisor definitely applies the trainings planned by HR. Our brand controllers come and check whether our standards are appropriate from the trainings here to the points we serve. This is the process, and the brand forces us to go through these processes. In other words, you are not authorized to make an independent decision, such as saying that we should not do this in this month. In other words, regarding the behaviors of the staff, their behavior with each other, their behavior towards the guests, and even the way they use materials, we provide their training. Our friends who have learned the simplest correct sales techniques support the reduction of our costs."

\subsection{Cost-based sales prices}

M1; "Our capacity is approximately twice as large as the largest among the other hotels in the city. Therefore, our total costs are higher than them, but we obtain more advantageous and more appropriate figures in unit costs. ... because the global agreements we have made are very important for us, especially at this point. Already, one of the most important issues in the accommodation industry in our age is cost. We consider cost in all our work. We sell every menu we sell, whether it be related to banquets or the events we do, according to the costs of the products. If there are changing points in daily sales, the new price is determined instantly by removing the cost. Nobody has the authority for sales that are not approved by accounting."

M3; "These affect our success, of course, we apply the stock system. For example, today we buy and stock 5 items and store them. From this point on, our cost process starts on inventories. If you have spent many years in the industry, you can also immediately notice situations that are more or less than normal. ... but we also support them with computers. We can see this immediately when portion standards are broken. We teach our servings to the newly recruited chef. Related chefs are responsible for their control and execution."

\subsection{Simple accounting applications}

M5; "So, we are already making daily turnover determinations. We compare expenses and income. If the hotel has not undergone a major renovation, we are continuing our standard work. We do not have a strict cost monitoring program."

Table 7. Cost and price balance understanding of managers

\begin{tabular}{ccc}
\hline Question 6 & Can you supply less cost than your competitors? \\
\hline Managers & & SUB THEMES \\
\hline M1 & Large capacity & Brand standard \\
\cline { 2 - 3 } & Competitors & Quality product \\
\cline { 2 - 3 } & Distributor companies & Competitors \\
\cline { 2 - 3 } & Total cost & At least seven different prices \\
\cline { 2 - 3 } & The unit cost & \\
\hline M1 & Global agreements & \\
\hline
\end{tabular}


Table 7 continued

\begin{tabular}{|c|c|c|}
\hline \multirow[t]{2}{*}{ M2 } & & Reaching multiple distributors \\
\hline & & Receive quotes \\
\hline \multirow[t]{3}{*}{ M3 } & & Purchasing agent \\
\hline & & Price research \\
\hline & & Quality research \\
\hline M4 & & Public tender \\
\hline \multicolumn{3}{|l|}{ M5 } \\
\hline \multicolumn{3}{|c|}{ THEMES } \\
\hline & High Price Value Perception & Price research at suppliers \\
\hline \multicolumn{3}{|c|}{ MAIN THEME } \\
\hline & COST AND PRICE BALANCE & \\
\hline
\end{tabular}

The themes that formed the consciousness of the managers towards cost and price balance were as "brand discount", "high price value perception" and "price research at suppliers". The sub-themes, themes and main themes shown in Table 7 formed based on the answers given by the managers to the sixth question "can you supply less cost than your competitors," and these statements are presented in Table 7.

\subsection{Brand discount}

M1; "Our capacity is approximately twice as large as the largest of the other hotels in the city. Therefore, our total costs are higher than them, but we obtain more advantageous and more appropriate figures in unit costs. ... because the global agreements we have made are very important for us, especially at this point. With these agreements, we buy more suitable products from the distributor companies here. In other words, the distributors who supply us with products buy more expensive products from us. This expresses the advantage that the brand has given us. Long-term agreements also give us bargaining power. The fact that this brand makes an agreement not only for this country but also for all hotels in the world constitutes a very large scale. This means that sellers will minimize their prices in order to make a deal with this brand."

\subsection{High price value perception}

M1; "It is true that we increase customer satisfaction due to the quality of the products we use, but we cannot say that we offer lower prices than local hotels here. We already have the obligation to use product quality at Garden Inn standards. On the contrary, others might use lower-quality products. For example, we have a cleaning brand named evilyn, we use it. There's only one distributor in Turkey that we do this with. We do not deviate from our personnel and product quality, and our costs are higher than our competitors. We have very strict instructions on materials that need to be used and renewed for fire precautions. These are all valid costs because we carry a brand. I can say that we definitely use the ones that are more suitable for us as a price benefit balance. Yes, it is more expensive, but we think it is a situation that increases customer satisfaction more than that price." 


\subsection{Price research at suppliers}

M2; "We go to wholesalers or the marketplace to buy vegetables from local markets. From there, we bring the necessary products at half the price. They are both fresher and more suitable products."

M3; "Of course, only in our trading group, we have an employee who takes care of these jobs. They conduct research, search for all the markets and negotiate according to our price policy and other criteria".

M4; "Of course, we are working on textile products and mattresses in accordance with the public procurement procedure in the near future".

\section{RESULT AND DISCUSSION}

Competition and awareness of competition were asked in the first question to learn which concepts appeared in the minds of the hotel managers. The hotel managers tried to explain their opinions about competition and awareness of competition through the themes of monitoring the external factors of the hotel, facilities and operating structure in competing hotels, using statistical data, managers' sector experience, service quality and decreasing prices. In the study of Köseoğlu et al. (2016), when the awareness levels of hotel managers about competition intelligence were investigated, the majority of the managers stated that they had not received any formal training on this issue before, while the rest emphasized their past experiences in this regard. In the study of Köseoğlu et al. (2016), similar to the themes of service quality and price reduction obtained for the first question of this study, it was seen that hotel managers use competitive practices to create competitive prices and business development. M5 stated that he was following other hotels, we see that the managers in Köseoğlu's (2016) study followed the same method and even tried to catch the strategies of international chain hotels due to their high research potential, but unlike Köseoğlu's (2016) study, none of the participants in this study stated that they followed international chain hotels especially and copied them exactly. M1, on the other hand, assessed that organizational structure and facilities are important in competition, but he stated that they had obtained their competitive experience from the environment created by star hotels with the same criteria. In this sense, he explained that he did not need to watch other hotels and only determined a strategy in accordance with official statistics. According to the theme of using official statistics from M1, we see that M1 supported the proposals of Hull and Covin (2010) regarding organizational learning. We may understand that the importance given to organizational learning and knowledge is effective in creating the competition strategy of M1's hotel. Unlike other studies, this study showed that hotel managers focus on the theme of lowering prices while expressing competition. While evaluating competition, we see that some managers think that competition is effective on the quality of service.

In the second question, the relationship between the distinguished talents of hotel staff and competitive advantage was asked to learn the concepts that were recalled in the minds of the hotel managers. The hotel managers tried to explain their opinions about distinctive skills and competitive advantage through their hotels' employment policy, staff turnover, information technology capability and customer relations. Most of the managers in this study stated that employing personnel with distinctive skills is limited due to the employment policy of their hotel. Only M1 among the hotel managers in this study defined technology capability as a distinctive organizational capability and recognized that their employment of personnel with this capability was effective in providing a competitive advantage. Only M1 also stated that recruiting talented staff contributed to their superiority in customer relations. In their 
study, Kumar et al. (2008) investigated the variables that affect technology ability in hotel businesses, and they determined that the independent variables that had the most important effect on this ability were the organizational structure and the systems and procedures applied in the organization.

Innovative products and services were asked in the third question to learn the concepts in the minds of the hotel managers. The hotel managers tried to explain their opinions about innovative products and services through different service concepts and using online channels. Backman et al. (2017) researched the variables that affect innovation at hotel establishments and different companies, and they found that the knowledge and abilities of employees had a positive effect on the innovative activities of companies, this effect was more significant than those of other variables in hotel businesses, and the knowledge and skills of the employees of hotel businesses were especially effective in the fields of service and marketing. This result supported the themes obtained from the third question of the study.

In the fourth question, we asked the participants what it meant to be in different markets than competitors to learn the concepts in the minds of the hotel managers. The hotel managers tried to explain their opinions about taking place in different markets than competitors through international markets and national local markets. Another study with a finding that supported the theme of providing services to differentiated markets was the study by Jönsson and Davonish (2008). In their research, among the eight different competition strategies practiced by the hotels they examined, providing services to different markets was in the second place.

In the fifth question, cost cutting systems and practices were asked to learn the concepts in the minds of the hotel managers. The hotel managers tried to explain their opinions about their cost cutting systems and practices through tight financial measures, cost-based sales prices and simple accounting applications. Implementing strict cost-cutting measures, as reported in a previous study (Akan et al., 2006), is a prerequisite for implementation of strategies. In this study, the hotel managers who stated that they had such practices were the managers of 4-star hotels. In the last question, when they were asked to compare their supplier relationship to their competitors, the hotel managers tried to explain their opinions by using the themes of brand discount, high price value perception and price research at suppliers.

The findings from this study are expected to contribute to RBV-based competition studies for the hospitality industry. This study is also expected to contribute to planning of special regions such as TRC1 regions, whose characteristics are mentioned above, where the tourism industry is aimed to be developed by public administrators.

\section{REFERENCES}

Acar, Z. (2010). The role of logistics capabilities on the strategy-performance relationship: A field research on SMEs. Atatürk University Journal of Economics and Administrative Sciences, 24, 1 21.

Akan, O., Allen, R. S., Helms, M. M., \& Spralls, SA. (2006). Critical tactics for implementing Porter's generic strategies. Journal of Business Strategy, 27, 43 - 53.

Akyol, B., Tanrısevdi, F., Gidiş, Y., Dumlu, N. N. \& Durdu, İ. (2020). Organizational culture at university: A sample of a State University, Faculty of Education Journal of Qualitative Research in Education, 8, 18-38.

Allen, R., Helms, M. M., Jones, H., Takeda, M. B., \& White, C.S. (2007). Porter's business strategies in Japan, Business Strategy Series, 9, 37-44. 
Allen, S. \& Helms, M. M. (2006). Linking strategic practices and organizational performance to Porter's generic strategies. Business Process Management Journal, 12, 433 - 454.

Amit, R. \& Schoemaker, P. J. (1993). Strategic assets and organisational rent. Strategic Management Journal, 14(1), 33-46.

Atak, M. \& Atik, İ. (2007). The importance of continuing education in organizations and its effect on learning organization formation. Journal of Aeronautics and Space Technologies, 3, 63-70.

Backman, M., Klaesson, J., \& Öner, Ö. (2017). Innovation in the hospitality industry: Firm or location? Tourism Economics, 23(8), 1591-1614

Barney, J. B. (1995). Looking inside for competitive advantage. Academy of Management Perspectives, 9, 49-61.

Barney, J.B. \& Hesterly, W. S. (2006). Strategic management and competitive advantage, Harlow, UK: Pearson, Prentice-Hall.

Bielinska-Kwapisz, A. (2014). Triggers of organizational change: Duration, previous changes and environment. Journal of Change Management, 14(3), 405 - 424.

Božič, V., \& Knežević Cvelbar, L. (2016). Resources and capabilities driving performance in the hotel industry. Tourism and Hospitality Management, 22(2), 225-246.

Creswell, J. W. (2014). Research design: Qualitative, quantitative, and mixed methods approaches. Los Angeles, USA: Sage.

Creswell, J. W. (2013). Qualitative inquiry \& research design: Choosing among five approaches. Los Angeles, USA: Sage

Dess, G.G. \& Davis, P.S. (1984). Porter's generic strategies as determinants of strategic group membership and performance, Academy of Management Journal, 26, 467 - 88.

Flick, U. (2013). Mapping the field. In U. Flick (Ed.), The SAGE handbook of qualitative data analysis (pp. 3-18). Los Angeles, USA: Sage.

González-Rodríguez, M. R., Jiménez-Caballero, J. L., Martín-Samper, R. C., Köseoglu, M. A., \& Okumus, F. (2018). Revisiting the link between business strategy and performance: Evidence from hotels. International Journal of Hospitality Management, 72, 21-31.

Göral, R. (2014). Strategic management in tourism businesses. Ankara; Detay Publishing.

Hinks, J. (1998). A conceptual model for the interrelationship between information technology and facilities management process capability. Facilities, 16, $233-245$.

Hooley, G., Broderick, A., \& Möller, K. (1998). Competitive positioning and the resource-based view of the firm. Journal of strategic marketing, 6(2), 97-116.

Hull, C. E., \& Covin, J. G. (2010). Learning capability, technological parity, and innovation mode use. Journal of Product Innovation Management, 27(1), 97-114.

Ivanova, M., \& Ivanov, S. (2016). Hotel chains conceptual models. In Ivanova, M., Ivanov, S., Magnini, V. (Eds.), Routledge handbook of hotel chain management (pp. 69-82), London: Routledge.

Jeng, J. D. \& Pak, A. (2016). The variable effects of dynamic capability by firm size: The interaction of innovation and marketing capabilities in competitive industries, International Entrepreneurship and Management Journal, 12, 115 - 130.

Jones, R. A., Jimmieson, N. L., \& Griffiths, A. (2005). The impact of organizational culture and reshaping capabilities on change implementation success: The mediating role of readiness for change. Journal of Management Studies, 42(2), 361-386.

Jönsson, C., \& Devonish, D. (2008). Does nationality, gender, and age affect travel motivation? A case of visitors to the Caribbean island of Barbados. Journal of Travel \& Tourism Marketing, 25(3-4), $398-408$ 
Kamasak, R., Yavuz, M., \& Altuntas, G. (2016). Is the relationship between innovation performance and knowledge management contingent on environmental dynamism and learning capability? Evidence from a turbulent market, Business Research, 9, $229-253$.

Kılınç, İ. \& Taşgit, Y. E. (2008). Porter's generic competition strategies in hotel businesses, In Okumuş, F. \& Avc1, U. (Eds), Contemporary management techniques in tourism businesses (pp. 237-250), Ankara, Detay Publishing,

Köseoglu, M. A., Chan, E. S., Okumus, F., \& Altin, M. (2019). How do hotels operationalize their competitive intelligence efforts into their management processes? Proposing a holistic model. International Journal of Hospitality Management, 83, 283-292.

Köseoglu, M. A., Ross, G., \& Okumus, F. (2016). Competitive intelligence practices in hotels. International Journal of Hospitality Management, 53, 161-172.

Kumar, U., Kumar, V., \& Grosbois, D. (2008). Development of technological capability by Cuban hospitality organizations. International Journal of hospitality management, 27(1), 12-22.

Law, V., T, P., \& Zhang, H. Q. (2015). An analysis of industry forces, strategic implementation, and performance: evidence from state-owned hotels in China, Journal of China Tourism Research, 11, $315-336$.

McCool-Kennedy, J. \& Sweeney, J. (2011). Reconceptualizing professional service firm innovation capability: Scale development, Industrial Marketing Management, 40, 1264-1273.

Meyer, C. B. \& Stensaker, I. G. (2006). Developing capacity for change, Journal of Change Management, 6, 217-231.

Muhanna, W.A. \& Stoel, M.D. (2010). How do investors value it? An empirical investigation of the value relevance of it capability and it spending across industries, Journal of Information Systems, 24, 43-66.

Najrani, M. (2016). The effect of change capability, learning capability and shared leadership on organizational agility, (Unpublished doctoral dissertation), Pepperdine University, Malibu.

Özen, Ü. \& Bingöl, M. (2007). Information technologies and innovation in businesses: A research in SMSs in Erzurum, Erzincan and Bayburt, Journal of Atatürk University Institute of Social Sciences, 10, $399-417$.

Patton, M. Q. (2014). Qualitative research and evaluation methods. (Çev: M. Bütün \& S. B. Demir), Ankara. Pegem Academy.

Peng, D. X., Liu, G. J., \& Heim, G. R. (2011). Impacts of information technology on mass customization capability of manufacturing plants. International Journal of Operations \& Production Management. 31, 1022 - 1047.

Prithwiraj, N., Subramanian, N. \& Ramakrishnan, R. (2010). The impact of marketing capability, operations capability and diversification strategy on performance: A resource-based view, Industrial Marketing Management, 39, 317-329.

Ross, D.N. (1999). Culture as a context for multinational business: a framework for assessing the strategy-culture 'fit, Multinational Business Review, 7, 13-9.

Ružić, M. D. (2015). Direct and indirect contribution of HRM practice to hotel company performance. International Journal of Hospitality Management, 49, 56-65.

Snow, C. \& Hrebiniak, L. (1980). Strategy, distinctive competence and organizational performance, Administrative Science Quarterly, 25, 317-336.

Soparnot, R. (2011). The concept of organizational change capacity, Journal of Organizational Change Management, 24, $640-661$. 
Suvac1, B. ve Tonuş, Z. (2015). Logistics activities performed in chain and group hotel enterprises and determination of required logistics resources, Journal of Travel and Hospitality Management, 12, 87-101.

Sweeney, J., Soutar, G. \& McColl-Kennedy, J. (2011). The marketing practices-performance relationship in professional service firms, Journal of Service Management, 22(3), 292-316.

Ülgen, H., Mirze, K.S. (2010). Strategic management in businesses, İstanbul. Beta Publishing.

Wernerfelt, B. (1984). A resource-based view of the firm, Strategic Management Journal, 5 (2), 171-180.

Whelan-Berry, S., Somerwille, A. K. (2010). Linking change drivers and the organizational change process a review and synthesis. Journal of Change Management, 10, 175-193.

White, R.E. (1996). Generic business strategies, organizational context, and performance: An empirical investigation. Strategic Management Journal, 7, 217-231.

Yorulmaz, M., Birgün, S. (2016). Literature research on logistics capabilities and determination of maritime transport logistics service capabilities. The Journal of Academic Social Science, 25, 313333.

Yusr, M. M. (2016). Innovation capability and its role in enhancing the relationship between TQM practices and innovation performance, Journal of Open Innovation: Technology, Market, and Complexity, 6, $1-15$.

Zhang, M. \& Tansuhaj, P. S. (2007). Information technology capability, and performance: The case of born global firms. Multinational Business Review, 15, 43-78.

Yazar(lar) Hakkında/About Author(s)

Eda Rukiye DÖNBAK/edonbak@adiyaman.edu.tr

Eda Rukiye DÖNBAK doktorasını Atatürk Üniversitesi, Sosyal Bilimler Enstitüsü, Turizm İşletmeciliği ve Otelcilik A.B.D.' da, yüksek lisansını Mersin Üniversitesi, Sosyal Bilimler Enstitüsü, Turizm İşletmeciliği ve Otelcilik A.B.D.' da tamamladı. Adıyaman Üniversitesi, Turizm Rehberliği Bölümünde Dr. Öğr. Üyesi olarak görev yapmaktadır. Çalışma alanları Turizm Rehberliği ve Turizm İşletmeciliğidir. Adres; Adıyaman Üniversitesi, Turizm Fakültesi, 02040 Merkez/ADIYAMAN 